\title{
The Effect of The Implementation of the IAS 39 on the Jordanian Investors
}

\author{
Dr.Khalil Nimer, Mohammed Idris, Dr. Saleh Al-Okdeh \& Dr. Mahmoud Nassar \\ Applied Science Private University
}

Received: April 27, 2011 Accepted: July 5, $2011 \quad$ doi:10.5539/ibr.v4n4p276

\begin{abstract}
IAS 39 has been described as being the most difficult standard to be implemented and understand The main aims of this research were to examine the effect of the implementation of IAS 39 on the investment's decisions of individuals and institutions in Jordan; to evaluate the understanding of IAS 39 by Jordanian investors and the effect of their understanding upon their investment decisions; and to examine the effect of some factors such as the degree of knowledge and the nature (individual or institution) of the investor on the degree of understanding of this IAS because. In the current study, Firstly, the results supported the first hypothesis that the implementation of IAS 39 would affect the reported profits of companies and, consequently, Jordanian investors would decrease their investment in these companies. Secondly, no significant differences were found between different fields of education, different professional certificates, and different years of experience with regards to the understanding of the implementation of IAS 39 and its effect; but, statistical differences were found between different levels of education at the $5 \%$ level, and between individual and institutional investors at the $10 \%$ level.
\end{abstract}

Keywords: International Accounting Standard, IAS 39, Fair value

\section{Introduction}

Jordan was one of the earliest developing countries to adopt International Accounting standards (IAS). They were adopted for public companies on the recommendation of the Jordanian Association of Certified Public Accountants (JACPA) in 1996. They replaced the existing Jordanian Accounting Standards (JAS), which had been introduced by Government Income Tax Department and the Amman Stock Exchange (ASE). The switch to IAS was carried out because those local Accounting Standards did not provide sufficient guidance for the preparation of annual reports. As a result of the implementation of IAS by listed companies, investors benefited from the additional financial information which IAS required companies to include in their annual reports (Rawashdeh, 2003).

In terms of the standards that are related to the disclosure of information relating to financial instruments, initially IAS 32 included all the relevant necessary regulations. In 1999, the International Accounting Standards Committee (IASC) assigned all issues related to the recognition and measurement of financial instruments to IAS 39 and it became effective in 2001 (IASC, 2000). The difference between these two standards lies in the method of measuring the financial assets excluding securities that are classified as being held to maturity.

Before the application of IAS 39, financial assets were recognised at historical cost, and measured on the basis of the conservatism principle at the lower of cost or market value. IAS 39 is concerned with the recognition and measurement of a company's financial assets and financial liabilities and reformed the recording of the financial assets within financial statements into three categories: (1) held for trading at fair value; (2) available for sale at fair value; and, (3) held to maturity at amortized cost (Kieso and Weygandt, 2007).

Securities valued at historical cost maintain the same value or decrease in value against their historical cost. Under fair value, securities are measured and evaluated according to their prices in a normal market. Securities prices are affected by the supply and demand volumes within the market and consequently, the fair value of such securities fluctuates in line with changes in the market, rather in relation to their historical cost. In other words, any revenues or losses result from the increase or decrease in the market value of financial assets is recognised by changes in fair value but completely ignored in valuation under historical cost.

Between mid-2003 and the end of 2009, the Amman Stock Exchange (ASE) recorded a huge volume of trades, largely through foreign investments following Jordan's adoption of a strategy of attracting foreign capital to enhance its economy through developing a sound climate for investment. This attracted both individual and institutional investors to invest in the equity market of ASE. However, it was not clear to what extent the investors were aware of the appropriate means of investing in the ASE. More precisely, it was not clear to which extent IAS 39 has influenced investor decisions. Within this context some questions arise: Do Jordanian investors focus upon the profit element when they make their decision of investment? Do they distinguish between the realised and the unrealised profit? If they do make this distinction, what effect does this have upon their investment decisions?

This study attempted to answer these questions. The main aims of this research were to examine the effect of the implementation of IAS 39 on the investment decisions of investors in Jordan (i.e., the individual and the institutional 
investors); to evaluate the understanding among Jordanian investors of IAS 39 and the effect of their understanding upon their investment decisions; and to differentiate between both individual and institutional investors according to their awareness and understanding of IAS 39.

As indicated above, listed Jordanian firms were obliged to adopt International Accounting Standards in 1996 instead of Jordanian Accounting Standards. As a result, Jordanian firms applied IAS 39, which was been described as being the most complicated international standard issued to date (Chiu, 2002).The application of such a standard in an inefficient market like ASE (see Atmeh, 2004, and Barghouthi, 2005) would be likely to have a significant impact upon the firms and investors in that market because firms had to switch to evaluating and measuring their financial instruments on the basis of fair value instead of historical cost leading to realised and unrealised profits and losses appearing in the financial statements.

As mentioned by (Wilson and Ernst \& Young, 2001) these unrealised profit may never be recognized and, in an inefficient market like ASE, investors may not be able to sell their shares at the market price when they want. As a result, their losses could be unaffordably high. This was the case particularly in the intermediaries and investment companies due to the high percentage that financial instruments represented of their total assets. Their performance indicators would, consequently, be significantly affected (Al-Khadash and Abdelateef, 2009).

This present study examines the impact of the implementation of IAS 39 on the investors' decisions investment in Jordan. The expected effect for the implementation of IAS 39 in Jordan was to increase the volatility of company profits, especially in those Jordanian companies with very high amount of investment (i.e., the investment companies), as a result of their recognizing the unrealised profit of their financial instruments. Therefore, it was expected that the implementation of IAS 39 in Jordan would affect the investors' decisions by decreasing investment in the investment and intermediaries companies. Accordingly, the first hypothesis of this research was:

H1: If the implementation of IAS 39 increased the volatilities of the investments and intermediaries companies' profits, investors would decrease their investment in these companies.

Because IAS 39 is considered one of the most complicated standards to interpret and apply, the second issue of this research was whether the Jordanian investors were aware of the implementation of IAS 39 or of its effect upon the content of financial statements relating to financial instruments. Therefore, the second hypothesis was:

H2: If the Jordanian investors are not aware of the implementation of IAS 39 or of its effect upon the content of financial statements relating to financial instruments, then, the investors would not decrease their investment in the investment and the intermediaries companies.

\section{Literature review}

\subsection{What is the fair value?}

Fair value was defined in IAS 16 (1993), "the amount for which an asset could be exchanged between knowledgeable, willing parties in an arm's length transaction." In 2009, the IASB defined fair value in its exposure draft on fair value measurement as, "the price that would be received to sell an asset or paid to transfer a liability in an orderly transaction between market participants at the measurement date."

The term "fair value" sometimes seems to be misleading especially when an instrument is not traded and there is uncertainty about the amount that might be paid or realised for it in a transaction between a buyer and seller in the market place. It might not be possible, in this case, to associate probabilities with future cash flows, which were necessary inputs into valuation model, because it does not express to users of financial statements that there was little market evidence to support the valuation: many possible estimates exist and any one of them could have been chosen and labelled "fair value" (Wilson and Ernst \& Young, 2001). Fair value may also cause highly volatile upwards and downwards adjustments of balance sheet and income statement, especially for the non-traded financial assets or for assets traded in illiquid markets (Barker, 2003).

\subsection{The Relevance of Fair Value}

Some authors (Barker, 2003; Chiu, 2002) focus on the relevance of fair value measurement for balance sheet reporting, but do not mention whether fair value is the most relevant characteristic for performance reporting. They also did not tackle the relevance of recognizing all fair value changes in earnings, nor the fact that fair value measurements are not used by management when evaluating business performance.

Within the context of the relevance of fair value, Ernst and Young conducted a survey with the European insurance companies in order to examine the acceptance of the use of fair value as a measurement for the financial instruments. Their results reported that the use of fair value has obtained favour among the European insurance companies, as fair value disclosure has become the market norm among European life insurance companies. However, a report published by Sirota consulting in 1998 mentioned that there was no consensus on the issue of reporting all financial instruments at fair value in the financial statements. In addition, the report noted that only " $a$ minority of 
participants were knowledgeable about fair value evenly divided between those who favoured requiring financial instruments to be recognized and measured at fair value in the financial statements, and those who did not think that such a major change was warranted" (Wilson and Ernst \& Young, 2001, p 27).

Accordingly, it is difficult to conclude that fair value always provides the relevant measure of performance because not all the holding gains and losses which are calculated on a fair value basis could be earned. In contrast, some of them might never be earned (Damant, 2002).

\subsection{The Reliability of Fair Value}

The question of whether values are reliable is a primary concern for most financial statements users, regulatory authorities, and auditors. Fair value is said to be more relevant than historical cost for measuring and evaluating financial instruments, because financial instruments may readily be converted to cash. Fair value is also said to be relevant because it is considered a proxy for a current market value. However, the market in these instruments is not generally very efficient and there is no guarantee that any market price will exist upon which to base the amount assigned. As a result, use of fair value can often result in the use of estimated prices for financial instruments.

If fair value of an instrument is subject to a wide range of probabilities, the amount assigned to it representing its fair value may not be an accurate reflection of its market value. Consequently, the relevance of the assigned amount is questionable because of its inherent lack of reliability (Wilson and Ernst \& Young, 2001).

The use of fair value would be more useful in evaluating financial instruments if the market was very efficient (i.e. very highly liquid and transparent). The market in this case would be sufficiently developed for the assigned amount to pass a test of its reliability (Chisnall, 2001).

In addition, estimates can be reached using several techniques, each of which is a valid one to adopt, but each of which produces a different fair value amount. Also, these estimates could depend on personal judgment, which is affected by many factors such as the future cash flows, the discount rates, price volatility, and the degree of the liquidity of the market (Hague, 2002), a point made against fair value by supporters of historical cost as the valuation basis.

\subsection{The Consistency of Fair Value}

Many fair value measurements are not produced from a defined process with consistent valuation methods. In addition, the broader use of fair value measurements to cover all the financial instruments that appear in the financial statements would worsen the reliability of the amounts shown. This creates many difficulties for the management, the auditors, and the external users of financial statements. Furthermore, creating a complete system in order to ensure the reliability and consistency of fair value measurements for all the financial instruments would require the creation of high cost valuation systems, data gathering systems, internal control systems, and the human resources to make the systems work, something which might be unaffordable for many corporations (Wilson and Ernst \& Young, 2001).

\subsection{The problem of Implementation of Fair Value}

Wilson and Ernst \& Young (2001, p.29) stressed that "certainly before the participating standard setters proceed towards issuing standards that broadly require fair measures in the primary financial statements, these issues must be addressed more comprehensively. Experiences with IAS 39 and FASB statement No 133 have shown that, before financial instruments standards can be applied in practice, there is a need for considerable guidance and interpretation. To avoid the protracted process of the ISAC's IGC and the FASB's DIG, which has caused the standards to be almost "unimplementable", it is imperative that the process for developing guidance and interpretation be completed before any new standard is issued"

Supporting this argument, Chiu (2002) provided an example about the implementation of IAS 39 in Singapore, the first Asian country to implement the standard, in January 2001. However, due to the complicity of the standard and the difficulty of its interpretation, which made companies unready for the implementation, implementation was postponed until January, 2004.

\subsection{Empirical studies relating to IAS 39}

Since IAS 39 was issued, very few studies have investigated its implementation or its effect, either on the companies themselves or on investors. Most of the studies that have investigated IAS 39 have done so in the context of developed countries. For example, a study conducted by Eckes and Hitchins (2002) aimed at finding how can European Union countries benefit from the experience of German banks in applying IAS 39. The study revealed the need of two years of preparation to substitute local accounting standards with the international accounting standards, in addition to the need of two further years to fulfill the requirements of creating a new documentation system and building an advanced technology needed to help promoting the complete transfer. Beate (2003) investigated the relation between shares market price and derivatives value in inactive markets and found that market prices of 
derivatives are inappropriate in such markets because the models used to calculate derivatives market values according to IAS 39 were not relevant in evaluating derivatives in inactive markets. Gary (2003) found some problems within the requirements of applying IAS 39 on held to maturity securities held by Banks. As securities under this category should be evaluated at amortized cost not fair value, and since banks have high sensitivity towards any changes in interest rates, the whole value of the bank and its profitability will be affected due to fixed interest rates. Therefore, the study recommended the use of fair value for securities held for hedging purposes.

A few studies have investigated IAS 39 within the context of developing countries. For example, Yassin (2006) examined the degree of understanding of Jordanian companies to IAS 39. The study employed questionnaires that were distributed to 61 listed Jordanian firms on the ASE in order to assess their abilities to understand and comply with IAS 39. The statistical results showed that $64 \%$ of the firms were capable to implement the IAS 39 efficiently. Al-Khadash and Abdelateef (2009) investigated the effect of fair value applications for financial assets under IAS 39 and IAS 32 on the financial performance and the Earnings per Share (EPS) of listed Jordanian banks. Their sample consisted of all banks in Jordan and they compared the results of these banks before and after the implementation of IAS 39. They found that the banks' performance indicators were significantly affected after the implementation of IAS 39 and their EPSs improved as a result of he switch to fair value as required by the standard.

\section{Research Methodology and Data Collection Methods}

This section aims at providing details concerning data collection, sample, and the adopted methods of data analysis.

\subsection{The context and sample of the study}

The population of this research comprised of all the investors in the ASE. These can be split into two groups: individuals and institutions. Accordingly, two groups were selected and included in a questionnaire survey in order to achieve the aims of this research. Details of these samples are as follow:

Individual investors: questionnaires were distributed by post to 100 individuals chosen at random from investors in the ASE. Sixty questionnaires were returned, seven of which were incomplete: a useable response rate of 53 per cent.

Institutional investors: the 51 Jordanian investment firms that existed in Jordan were all included in the survey. A self-administrated approach was employed in order, as postal questionnaires were considered to be an ineffective way of distributing questionnaires to these firms. Forty-seven companies responded and completed the questionnaire, a response rate of 92 per cent. Table 1 presents both samples and the respondents' percentages.

\subsection{Methods of Data Collecting and Analysing}

Data relating to this research has been collected from a range of sources. The literature, the published data of ASE and the ISAC, and the financial statements of some listed Jordanian investment companies. Empirical data was collected through a questionnaire survey, which was distributed to a large sample of investors consists of both individuals and institutions. A range of statistical techniques were used in analysing this data such as frequencies and percentage, mean, and standard deviations. In addition, some non-parametric techniques were used because they were more suitable with the categorical data. More precisely, Friedman test of variance was used in order to rank the most important factors that would influence the investment of the Jordanian investors, Mann-Whitney test of variance was used to examine the variation between two independent samples, and Kruskal-Wallis test of variance was employed in order to examine the variation of the awareness of the Jordanian investors toward IAS 39 between different groups.

\section{Survey Results and Analysis}

\subsection{The Investors' knowledge concerning IAS 39}

Four variables were used as proxies for the investors' knowledge; the field of education, the levels of education, the professional knowledge, and the experience. The following is an explanation of each of these variables.

Firstly, the level of education of the Individual investors or decision makers in the investment companies were expected to impact the knowledge concerning IAS 39 and its effect, as investors with higher levels of education should have higher capabilities of analyzing the financial statements and distinguishing between the realised and unrealised profit or losses. Therefore, the respondents were asked first to identify their levels of education from a high school to a $\mathrm{PhD}$ level. Based on our results, the majority of respondents, $80 \%$ held an undergraduate degree, while $20 \%$ held a postgraduate degree.

Secondly, the field of education was expected to impact the knowledge of the investors concerning IAS 39 and its effect, as the specialist in accounting should have higher knowledge with regards to the International Accounting Standards and have higher capabilities of analyzing their effect than other specialists. Therefore, the respondents were asked to indicate their field of education among the business knowledge fields or they can indicate "other" if they were specialists in other fields. Based on our results, $21 \%$ of respondents had specialist in accounting. 
Thirdly, professional knowledge referred to the investors or the decision makers who hold a professional certificate such as CPA, CMA, CFA, CIMA or ACCA. Investors who have such a profession were expected to have higher knowledge concerning the impact of IAS 39, and therefore, respondents were asked to indicate whether they have one of these certificates. This was a binary variable as " 1 " indicated to the investor who has one of the professional certificate, and "zero" otherwise. Based on our results, $38 \%$ of respondents had at least one of the professional certificates.

Finally, the experience of dealing with shares and analyzing financial statements would affect the knowledge with regards the effect of IAS 39 on the companies' profits, and in turn, on the shares' prices. Therefore, the respondents were asked to indicate their experience into categories. Based on our analyses, $13 \%$ of respondents had experience less than 3 years and $35 \%$ of respondents had experience of dealing with shares and analysing financial statement between 3 to less than 6 years, while $52 \%$ had experience more than 6 years.

\subsection{The factors that influence the investment decision}

IAS 39 changed the way of measuring and recognizing financial instruments, by requiring the use of fair value measurement. The expected impact of implementation of IAS 39 in Jordan was likely to have been higher in investments companies due to the concentration of their assets in financial instruments. This, in turn, would be expected to increase the volatility of profits for these companies. In order to explore whether the company profits and consistency of profit are important factors for Jordanian investors, Jordanian companies were asked to rank the factors that influence their investment decision from 1 to 5 , with " 1 " being not important to " 5 " being very important. As mentioned above, the Friedman two-way analysis of variance by ranks was used to compare $\mathrm{K}$ population means on the question relating to the importance of the factors that influence the investment decisions. If the null hypothesis is true, there is no difference in the ranks assigned to the importance of factors that influence the decision investments. Table 2 illustrated the results of Friedman test.

As the table revealed, the number of outstanding shares, profitability, and profit consistency were the most important factors that the Jordanian investors (both Individual investors and Institutional investors) take into consideration when they invest. These primary results supported the previous argument about the effect of the implementation of IAS 39 on the company's profit and the profit consistency. Nevertheless, these finding required further analysis in order to be meaningful. Examining the first hypothesis, if the implementation of IAS 39 increased the volatilities of the investments and intermediaries companies' profits, then the investors would decreased their investment in these companies, would provide further evidence about whether Jordanian investors decreased their investment in the intermediaries and investment companies due to the implementation of IAS 39. In order to examine this hypothesis, the Jordanian investors were asked to rank the sectors, the profit, and the profit's volatilities according to their investment during the last three years (i.e., following the period of the implementation of IAS 39). Table 3 explained the results of Friedman test of variance about these three elements.

As Table 3 revealed the investment in the intermediaries and investment companies were ranked by the Jordanian investors as fourth with a mean rank of 2.89, and so supported the hypothesis. Moreover, the respondents ranked the profit of the intermediaries and investment companies as fourth achieving less profit, during the last three years, than services, manufacturing, and banking sectors. Only the commercial sectors was ranked after the investment sectors, achieving the least profit. It was also ranked last in the number of investments, which could be attributed to the very limited number of commercial companies that are listed on the ASE. The last and the most important variable that the Jordanian investors were asked to rank in order to explore the hypothesis was profit volatility. As expected, the intermediaries and investment company profits were ranked as the most volatile of all the sectors by the Jordanian investors with mean rank 3.41, followed by the services' companies profit with a mean rank 3.15.

These results support the hypothesis and suggest that the sector of a company and its profit volatility are among the important factors that might affect investment decisions of Jordanian investors. The implementation of IAS 39 affected the firms which have high financial investments due to evaluating their financial instruments on a fair value basis and consequently increased the volatilities of their profit significantly due to the inconsistent of measurements. However, as was mentioned in section 1, this profit may never be recognized, especially in a developing and immature market like ASE, where shares price volatility is high and where many non-financial factors play a major role in determining share price. This in turn suggests that the volatility of these unrealised profits would also be high. Intermediaries and investment companies were the major sectors affected by adoption of IAS 39 in Jordan as most of their assets are represented by financial instruments, which explains why they were ranked as having the highest volatility in profit and caused investment in them to decrease.

\subsection{The Awareness of the Jordanian Investors about the implementation of IAS 39}

The previous section provided evidence concerning the effect of the implementation of IAS 39 on the profit of the intermediaries and investments companies, and in turn, on their shares prices which caused Jordanian investors to decrease their investments in these companies. This section examines the second hypothesis that investigated 
whether Jordanian investors aware about the implementation of the IAS 39 and its effect or their reaction was just a natural response to the market prices.

Several non-parametric statistical techniques were used in order to examine the second hypothesis because they were more suitable with the categorical data and offer more flexibility (De Vaus, 2002). The non-parametric equivalent of the one-way ANOVA is the Kruskal-Wallis one-way analysis of variance. This test was employed to examine the variations of the awareness of the implementation of IAS 39 and its effect between different group of investors with different education and experience. If the tests showed differences between the means of the groups at the $5 \%$ level of significance, the null hypothesis would be rejected. We concluded that there were significant differences in the degree of awareness according to different levels or fields of education or experience (Kinnear and Gray, 1999 and Cramer, 1998). Moreover, a Mann-Whitney test was employed in order to examine the variation between the two groups of respondents.

Investors who do not analyse the financial statements of the companies in which they are considering investing in would not be interested to know about a new IAS as their investment policies rely on other factors such as the market trend, a piece of information about integration or dividends, or the names of the board of directors. As a result, in order to examine the second hypothesis it was essential to distinguish between the investors according to their investment policy. Jordanian investors were, therefore, asked to indicate their investment policies, and Table 4 summarises the responses.

As the table shows, one-third of the sample respondents did not analyse the financial statements of the companies in which they invested, and most of them (75\%) relied upon a piece of information about one of the companies in deciding whether or not to buy its shares. These responses provided an indicator of the awareness of Jordanian investors toward IAS 39 and its effect, as $33 \%$ of the sample did not even analyse the financial statements of the companies in which they invested. in order to examine whether there were differences between the investors who did analyse the financial statements of companies in which they invested and investors who did not according to their awareness variables and with regards to the nature of the investors (i.e., individual or institutional), a Mann-Whitney test of variance was employed, and table 5 shown the results of this test.

The table revealed that there were significant differences at the $5 \%$ level of significance between investors in the analysis of the financial statements of the companies in which they invested according to their field of education, their professional certificates, and upon whether the investor was an individual or an institution; and according to their experience at the $10 \%$ level. These results support the hypothesis in suggesting that investors who have degree in accounting or finance, who have professional certificates, and who have greater experience analyse the financial statements of the firms that they invested in. in addition, the test revealed that institutional investors were more likely to analyse financial statement than individual investors, and this could be attributed to their having experienced and highly qualified staff to carry out the analysis.

Following this question, investors who indicated that they analysed the financial statements of companies in which they invested were asked to indicate whether they distinguished between realised and unrealised profit. Table 6 presents the responses to this question.

As the table shows, the large majority (92.5\%) reported that they distinguished between realised and unrealised profit when making investment decisions. In order to examine whether there were differences in the answer of the previous question according to the variables of the degree of awareness and whether the investor was an individual or institution, a Mann-Whitney test of variance was employed, and the results are shown in Table 7.

Table 7 reveals that none of the variables exhibited significant differences between individual and institutional investors or according to the awareness variables with regards of distinguishing between realised and the unrealised profits. This result could be attributed to the big difference in the number of observations between the investors who distinguished (5) and who did not distinguish (62) between the realised and the unrealised profits.

Finally, the investors were asked some questions that revealed the degree of their understandable to the IAS 39 and its effect. In each case, they were asked to indicate their agreement with a statement using the scale 1 to 5 , with " 1 " being 'strongly do not agree' and "5" being 'strongly agree' about. Investors were then divided into three groups coded from " 1 " for investors who did not understand the IAS 39 and its effect, to " 3 " for investors who understood the IAS 39 and its effect. Table 8 illustrates the differences between investors in their understanding of the IAS 39 according to their degree of awareness and whether the investors were individuals and institutions by the use of Kruskal-Wallis test of variance.

As Table 8 shows, only the level of education among the variables of the degree of awareness have reported significant differences with regards to the understanding of IAS 39 and its effect. This result suggests that investors with a higher level of education were more likely to understand IAS 39 and its effect. The differences in understanding of IAS 39 between the individual and institutional investors were significant at the $10 \%$ level only. 
These results could be attributed to the difficulties of understanding and applying the IAS 39, as it was considered by many researchers and authors as the most difficult and complicated international accounting standard (Gebhardt, et al, 2003).

In addition, this study provided evidence supported many of the results of the previous studies (Barghouthi, 2005) concerning the policies that the Jordanian investors followed when they invest in the ASE, as the majority of the investors (both individual and institutions) do not analyze the financial statements of the companies which they invest in. Instead, they rely on following the trend of the market or relying on one piece of information. This supported the previous results concerning the understanding of IAS 39, as investors who do not analyze the financial statements would not be interested to understand IAS 39 or its effect. Moreover, many previous studies found that the ASE is inefficient at the weak form level (see, for example, Attemeh, 2003; Barghoughti, 2005) and, consequently, the application of IAS 39 would be difficult in a market like ASE, because the market price does not always reflect the real price that the owner of the stock could sell it at, something that has happened many times in the ASE.

\section{Discussion and Conclusion}

This study investigated the implementation of IAS 39 and its effect on Jordanian investors, Jordanian investors were asked to answer a range of question that explores their investment policies, the effect of the implementation of the IAS 39 on their investment, and their understanding to the implementation of IAS 39 and its effect.

Analysis of the responses suggests that the most important variables that the Jordanian investors take into consideration when they invest were the profitability of the company, the consistency of income, and the number of outstanding shares. These results revealed the importance of the companies' profit and its consistency for Jordanian investors, which are the most affected variables by the implementation of IAS 39.

The results also revealed that both the institutional and individual Jordanian investors decreased their investment in the last three years in the intermediaries and investment companies, and this was attributed to the high volatility of their profit due to the concentration of their assets of financial instruments, which were the most affected by the implementation of IAS 39. These results supported the first hypothesis that the implementation of IAS 39 would affect the intermediaries and investment companies' profit and, consequently, Jordanian investors would decrease their investment in these companies.

In order to examine the second hypothesis, four variables were employed as proxies for the awareness of the Jordanian investors: the field of education, the level of education, the holding of a professional accounting qualification, and experience in investment. The results of the analysis found that one-third of the sample did not analyze the financial statements of the companies that they invested in, and that 92.5 per cent of those who did analyze them, reported that they could distinguish between the realized and the unrealized profits in the financial statements. However, many of those investors indicated that they did not take this point into consideration when they make their investment decisions.

The statistical results could not provide differences between different fields of education, different professional certificates, and different years of experience with regards to the understanding of the implementation of IAS 39 and its effect, but found statistical differences between different levels of education at the $5 \%$ level, and between individual and institutional investors at the $10 \%$ level. These results were attributed to the difficulties of IAS 39 implementation and application. In addition, institutional investors could clearly call on more experienced and qualified staff compared to each of the single individual investors, which explains the difference in the understanding of IAS 39 between the two groups.

In sum, the responses from the Jordanian investors revealed that a minority of them understand the implementation of IAS 39 and its effect; that many of them invest in the market based on a single piece of information or follow the big investors and the general trend of the market; and that they do not analyze the financial statement of the companies in which they invest. In addition, many of them indicated that they could distinguish between the realized and the unrealized profits that appeared in the financial statements but reported that they did not rely heavily on this piece of information when they invest and, consequently, the increase in unrealized profits as a consequence of implementing IAS 39 would not affect their investment decisions. Even if the investors understand the implementation of IAS 39, but they could not evaluate its effect or, if they could, they believed that the prices of the shares fluctuated as a response to different factors that might not be related to financial variables like profit and profit volatility.

\section{References}

Allister W and Earnest, Y. (2001). Fair value and measurement: Where the conflicts lie, Balance Sheet, VOL.9, NO.4, pp. 26-33. doi:10.1108/09657960110696735, http://dx.doi.org/10.1108/09657960110696735 
Al-Khadash. H and Abdelateef. M (2009). Consequences for Fair Value Accounting for Financial Instruments in the Developing Countries: The Case of the Banking Sector in Jordan. Jordan Journal of Business Administration, Vol. 5 , No 4.

Atmeh, M. (2003). Financial market efficiency: the case of Jordan, PhD thesis, Newcastle University, Newcastle, U.K.

Barghouthi, S. (2005). The efficiency of Amman financial market: An empirical study, PhD thesis, Manchester Metropolitan University, Graduate school of business, Manchester, U.K.

Barker, R. (2003). The revolution ahead in financial reporting: reporting financial performance, Balance Sheet, Vol.11, No.4, pp. 19-23. doi:10.1108/09657960310502502, http://dx.doi.org/10.1108/09657960310502502

Beate, J. (2003). Problems associated with the value-relevance of financial derivatives according to IAS 39, working paper series in Business administration, Stockholm school of Economics, No.

Chisnall, P. (2001). Fair value accounting - An industry view, Balance Sheet, Vol.9, No.1, pp. $27-33$. doi:10.1108/09657960110695259, http://dx.doi.org/10.1108/09657960110695259

Chiu, C. (2002). A need for preparation, www.asiarisk.com.hk

Cramer, D. (1998). Fundamental statistics for special research: step by step calculations and computing by using SPSS for windows, Routledge, London

Damant, D. (2002). A revolution in financial reporting, Balance Sheet, VOL.10, NO.1, pp. 4-7. doi:10.1108/09657960210697337, http://dx.doi.org/10.1108/09657960210697337

Damant, D. (2002). Financial instruments: fair values and disclosure, Balance Sheet, VOL.10, NO.1, pp. 12-19. doi:10.1108/09657960210697355, http://dx.doi.org/10.1108/09657960210697355

De Vaus, D. (2002). Analysing social science data, London, SAGE.

Eckes, B., and Hitchins, J. (2003). The implementation of IAS 39 in the Banking industry, Tackling the key issues in banking and capital markets, pp. 34-39

Gebhardt, G., Reichardt, R., and Wittenbrink, C. (2004). Accounting for financial instruments in the banking industry: Conclusions from a simulation model, European Accounting Review, Vol. 13, No. 2, pp. 341. doi:10.1080/0963818042000204733a, http://dx.doi.org/10.1080/0963818042000204733a

Gray, R. (2003). Research Note: Revisiting fair value accounting - Measuring commercial Banks' liabilities, ABACUS, Vol. 39, No. 2, pp. 250-261. doi:10.1111/1467-6281.t01-1-00129, http://dx.doi.org/10.1111/1467-6281.t01-1-00129

Hague, I. (2002). Fair value for financial instrument - where to next?, Balance Sheet, Vol.10, No.1, pp. 8-11. doi:10.1108/09657960210697346, http://dx.doi.org/10.1108/09657960210697346

International Accounting Standards Committee (2000), International Accounting tandards, International Accounting Standards Committee.

Kieso, D., Weygandt. J (2007). Fundamentals of intermediate accounting, $12^{\text {th }}$ edition, John Wiley \& Sons, Inc.

Kinnear, P., Gray, C. (1999). SPSS for windows made simple, Sussex, psychology press Ltd.

Rawashdeh, M. (2003),. Effects of introducing international accounting standards on Amman stock exchange, Journal of American academy of business, VOL. 3, September, pp. 361-366

Yassin, A. (2006). The extent of understand and compliance with IAS for financial accounting instrument: (IAS 32 and IAS 39) requirements in Jordanian shareholding listed companies, PhD thesis, Arab Academy for Banking and financial sciences, Amman, Jordan

Table 1. response rate

\begin{tabular}{|l|c|c|c|c|}
\hline \multicolumn{1}{|c|}{ Sector } & Total samples & Respondent & Non- respondent & Response rate \\
\hline Individual investors & 100 & 53 & 47 & $53 \%$ \\
\hline Institutional Investors & 51 & 47 & 4 & $92 \%$ \\
\hline Total & 151 & 100 & 51 & $66 \%$ \\
\hline
\end{tabular}


Table 2. The Friedman test of variance for the factors that influence the Jordanian investors' decision

\begin{tabular}{|c|c|c|c|c|c|c|c|}
\hline \multirow{2}{*}{$\begin{array}{l}\text { The factor } \\
\text { Firm's activities }\end{array}$} & \multicolumn{3}{|c|}{ Not important at all } & \multicolumn{2}{|c|}{ very important } & \multirow{2}{*}{$\begin{array}{l}\mathrm{N} \\
100 \\
\end{array}$} & \multirow{2}{*}{$\begin{array}{l}\text { Mean Rank } \\
4.09\end{array}$} \\
\hline & 3 & 8 & 16 & 28 & 45 & & \\
\hline Firm Size & 1 & 11 & 25 & 27 & 36 & 100 & 3.65 \\
\hline Firm's profitability & - & 6 & 18 & 20 & 56 & 100 & 4.55 \\
\hline Profit consistency & 1 & 6 & 19 & 31 & 43 & 100 & 4.22 \\
\hline Number of outstanding shares & 1 & 4 & 12 & 24 & 59 & 100 & 4.64 \\
\hline The price of the share & 4 & 10 & 27 & 15 & 44 & 100 & 3.83 \\
\hline Firm's age & 11 & 13 & 24 & 26 & 26 & 100 & 3.02 \\
\hline
\end{tabular}

Note: the mean rank is generated by the Friedman two-way analysis of variance by ranks. The Chi-Square statistic is 54.969 , significant at 0.001 .

Table 3. The Friedman test of variance for the sector, profit, and profit's volatilities according to the investments of the Jordanian investors in the last three years

\begin{tabular}{|l|c|c|c|c|}
\hline \multicolumn{1}{|c|}{ The Sector } & N & Rank of Sectors & Rank of Profit & Rank of Profit's Volatilities \\
\hline Commercial companies & 100 & 2.28 & 2.36 & 2.85 \\
\hline Services Companies & 100 & 3.72 & 3.39 & 3.15 \\
\hline Banking & 100 & 3.21 & 3.42 & 2.88 \\
\hline Manufacturing Companies & 100 & 2.9 & 3.05 & 2.68 \\
\hline Investment Companies & 100 & 2.89 & 2.79 & 3.41 \\
\hline
\end{tabular}

*Sector: the mean rank is generated by the Friedman two-way analysis of variance by ranks. The Chi-Square statistic is 44.720 , significant at 0.001 .

*Profit: the mean rank is generated by the Friedman two-way analysis of variance by ranks. The Chi-Square statistic is 31.746 , significant at 0.001 .

*Profit's volatility: the mean rank is generated by the Friedman two-way analysis of variance by ranks. The Chi-Square statistic is 13.592 , significant at 0.05 .

Table 4. The distribution of the Jordanian investors according to their investments policies

\begin{tabular}{|l|l|l|l|}
\hline \multicolumn{1}{|c|}{ The investment policy } & \multicolumn{1}{c|}{ Yes } & No & Total \\
\hline Analysing the financial statements & 67 & 33 & 100 \\
\hline Waiting for a piece of information & 76 & 24 & 100 \\
\hline Underwriting in the new floatation & 36 & 64 & 100 \\
\hline Following the trend of the market & 56 & 44 & 100 \\
\hline Rely on the names of the board of directors & 46 & 54 & 100 \\
\hline
\end{tabular}

Table 5. The variations between investors in analysing their financial statements according to their degree of awareness and whether they were individuals or institutions

\begin{tabular}{|l|l|l|l|l|l|}
\hline & \multicolumn{1}{|c|}{$\begin{array}{c}\text { Level of } \\
\text { education }\end{array}$} & $\begin{array}{c}\text { Field of } \\
\text { education }\end{array}$ & $\begin{array}{c}\text { Professional } \\
\text { certificate }\end{array}$ & \multicolumn{1}{|c|}{ Experience } & \multicolumn{1}{|c|}{$\begin{array}{c}\text { Individual or } \\
\text { institution }\end{array}$} \\
\hline Mann-Whitney & 782.000 & 729.000 & 755.000 & 837.500 & 661.500 \\
\hline Wilcoxon W & 1310.000 & 3007.000 & 3033.000 & 1365.500 & 1189.500 \\
\hline Z Value & -2.513 & -2.620 & -2.761 & -1.829 & -3.414 \\
\hline Significance & $0.012^{*}$ & $0.009^{* *}$ & $0.006^{* *}$ & $0.067^{*}$ & $0.001^{* *}$ \\
\hline
\end{tabular}

* Significance at 0.05

** Significance at 0.01

Table 6. The distribution of the respondents according to their distinguishing between the realised and unrealised profit

\begin{tabular}{|c|c|c|}
\hline Earned and unearned & Frequency & Percentage \\
\hline Yes & 62 & $92.5 \%$ \\
\hline No & 5 & $7.5 \%$ \\
\hline Total & 67 & $100 \%$ \\
\hline
\end{tabular}


Table 7. The variations between investors in distinguishing between realised and unrealised profits according to their degree of awareness and whether they were individuals or institutions.

\begin{tabular}{|l|c|c|c|c|c|}
\hline & Level of education & Field of education & Professional certificate & Experience & Individual or institution \\
\hline Mann-Whitney & 121.000 & 147.000 & 143.500 & 148.000 & 120.000 \\
\hline Wilcoxon W & 2074.000 & 2100.000 & 2096.500 & 163.000 & 2073.000 \\
\hline Z Value & -0.884 & -0.227 & -0.282 & -0.185 & -0.872 \\
\hline Significance & 0.377 & 0.820 & 0.778 & 0.853 & 0.383 \\
\hline
\end{tabular}

* Significance at 0.05

** Significance at 0.01

Table 8. The variations between investors who understood and did not understand the IAS 39 and its effect according to their degree of awareness and whether they were individuals or institutions.

\begin{tabular}{|l|l|l|l|l|l|}
\hline & \multicolumn{1}{|c|}{ Level of education } & Field of education & \multicolumn{1}{|c|}{$\begin{array}{c}\text { Professional } \\
\text { certificate }\end{array}$} & \multicolumn{1}{|c|}{$\begin{array}{c}\text { Experience } \\
\text { institution }\end{array}$} \\
\hline Chi-Square & 10.531 & 1.025 & 0.21 & 1.794 & 4.654 \\
\hline Significance & $0.005^{* *}$ & 0.599 & 0.989 & 0.408 & $0.098^{*}$ \\
\hline
\end{tabular}

* Significance at 0.05

** Significance at 0.01 